\title{
REPORT ON A BRIEF SURVEY OF THE WILD LIFE RESOURCES OF NEPAL, INCLUDING THE RHINOCEROS
}

\author{
MARCH, 1963 \\ Prepared for the Fauna Preservation Society \\ By E. P. Gee, M.A., C.M.Z.S.
}

\section{FOREWORD}

This is the second report which Mr. E. P. Gee has made upon the situation of the wild life of Nepal. His first, restricted to the Great Indian Rhinoceros, was made in 1959 at the behest of the Survival Service Commission of the International Union for Conservation of Nature.

Unfortunately, owing to political unrest, Gee's recommendations could not be followed by sufficient action. Nevertheless his visit resulted in so much interest both locally and internationally in the preservation of the rhinoceros, that the Fauna Preservation Society decided to ask him to go again this year.

Mr. Gee is uniquely fitted for his task. His widespread knowledge of the wild life of the Indian sub-continent is demonstrated by his surveys of the brow-antlered deer and of the wild ass and by his reports on the Kashmir stag and the Asiatic lion. It has been his work more than that of any other man which has ensured the survival of the Great Indian Rhinoceros in its other home-the wild life sanctuaries of Assam and Bengal.

Therefore both the Fauna Preservation Society and the Survival Service Commission recommend this present report to the Government of Nepal with complete confidence, not only for consideration, but also for urgent action.

$$
\text { C. L. Boyle. }
$$

Secretary, The Fauna Preservation Society. Chairman, Survival Service Commission. 


\section{INTRODUCTION}

In March, 1963, I made a second visit to Nepal at the request of the Fauna Preservation Society of London, whose Council and Members have always shown great concern over the survival, in that country, of the Great Indian Rhinoceros, and also at the invitation of R. G. M. Willan, Chief Conservator of Forests.

This Report should be regarded as a continuation of my earlier " Report on a Survey of the Rhinoceros Area of Nepal, March and April, 1959", published in Oryx, in August, 1959.*

\section{General Review and Summary of RePort}

The period immediately following my 1959 visit was politically unsettled, and the general situation in the Rapti Valley deteriorated. So, far from following the recommendation in my Report and making extensions to the north and to the south of the Mahendra National Park, the park actually became invaded at two places by settlers and was discontinued as a national park-partly because the required legislation had never been enacted.

The estimated number of rhino in Nepal dwindled from 300 in 1959 to 160 in 1961 due to increased poaching, but by 1962, after the re-establishment of more settled conditions, this number had risen to 185 .

There is now a more stable Government, with more law and order. Improved co-ordination between different Government Departments has resulted from the establishment of a Planning Council, and the outlook for the future seems decidedly better now than ever before.

For the preservation of the country's flora and fauna, as well as for the development of tourism in order to obtain more foreign exchange, it is necessary to constitute national parks and sanctuaries both in the terai for low elevation fauna and also in the Himalayas for high elevation fauna. The valuable fish resources need to be managed and made use of.

\section{HISTORICAL}

After the elections of March, 1959, a parliamentary and democratic system of government was tried, but apparently found unsuccessful; for in December, 1960, the King dissolved parliament and took over the administration of the country, assisted by a Ministerial Council.

Early in 1963 fresh elections took place for a Panchayat $\dagger$ system of government, and Panchayats have since come into being at all levels from villages upwards. The National Panchayat was inaugurated in April, 1963.

It is most gratifying to learn that most of the nominated Ministers of the former Ministerial Council have been re-elected in the new elections, and are in the new Cabinet.

The influx into the Rapti Valley of settlers, both authorized and unauthorized, which had been taking place appears to have continued unabated. In two places the 68 sq.-mile Mahendra National Park was

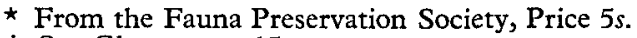

† See Glossary, p. 15. 
" invaded" to the extent of nearly 2 sq. miles. These incursions by settlers into the national park could not be prevented because the park had not been properly and legally constituted by an act, but was only "declared " as such by the Forest Department ; and it was wrongly supposed that the formal opening of this park in January, 1959, by the King himself would accord to it some legal status. This "mistake" will no doubt be a reminder in the future that there must be sound planning and proper legislation for each new national park.

The apparent lack of co-ordination between different Ministries and Departments, which led to confusion and indiscriminate allocation of land to both legal and illegal settlers from the hills into the Rapti Valley, seems now to have been rectified. During my stay in Kathmandu I was privileged to meet and discuss nature conservation with several members of the new Planning Council.

\section{Geographical and Ecological}

Most of my 1959 Report dealt with the Rapti Valley or Chitawan, which with the adjacent Reu Valley forms the rhinoceros area of Nepal. This is dun country, with some of the typical terai vegetation. This present Report, though briefer than the earlier one, covers the whole country. For its purpose, Nepal may be regarded as elongated and divided laterally from west to east by :-

(i) the southernmost narrow tract of terai or moist, flat country about 350-600 feet above sea level, mainly now under rice cultivation,

(ii) the narrow strip of bhabar or dry land with a subsoil of boulders about 600-800 feet above sea level, mainly under sal forest (Shorea robusta),

(iii) the Churia Range, or Siwalik Hills, from 800 feet to just over 6,000 feet, the lower ranges of which are mostly under sal forest, and

(iv) the Mahabharat or mountainous middle belt, and then the Himalayan Ranges up to 29,000 feet.

The rivers run mainly from north to south, and consist of many large ones with numerous tributaries, rich in fish.

\section{Administrative and Political}

A Forest Act came into operation in January, 1962, and a Wild Life Conservation Act in April of the same year. The Chief Conservator of Forests (under the United Nations Technical Aid Organization) is Mr. R. G. M. Willan. The Forest Department appears to be much better organized than in 1959 and is working with greater zeal and interest. Working Plans are being drawn up for the proper and planned use of the country's forestry resources. The time is now ripe to review the mistakes of the past and to make new plans for the development, management, and wise use of the country's wild life resources.

The Mahendra National Park seems to have been "discontinued" as such, following the incursion into it of so many settlers who have occupied most of the low-lying rhinoceros habitat of the park. But as this park still contains some wild life and some very fine scenery on the rivers Kali Gandaki and Mershiandi which unite to form the Narayani, I consider it 
imperative that it be properly and legally re-constituted as a national park, after excluding the settled areas but including an additional area in the north.

Most of the area of the valley north of the river Rapti has by now been occupied by settlers, and only those parts south of this river, and in the Reu Valley, are now available for preservation of flora and fauna. A dam is being constructed on the Khagri Khola stream in order to divert the water westwards for irrigation, thus nullifying my proposal in 1959 for this strip of land to be included in the Mahendra National Park as a corridor for seasonal migration of the rhino.

The rest of the southward extension of the park, which I proposed in 1959 , is mostly still unspoilt and uninvaded by settlers. This includes the area south of the Rapti, and the upper reaches of the Reu Valley. This area should be constituted as a new national park, and more details are given later of this proposal.

The Rhino Guards who are responsible for the protection of the rhino, are under a Wild Life Officer and now number 222. They consist of one Commander, five Subedars, twenty-two Havildars, and 194 Guards.

Ninety per cent are ex-servicemen. They have one jeep and four bicycles at their disposal, and are now armed with Lee Enfield rifles.

Estimates of the number of rhino year by year are as follows :-

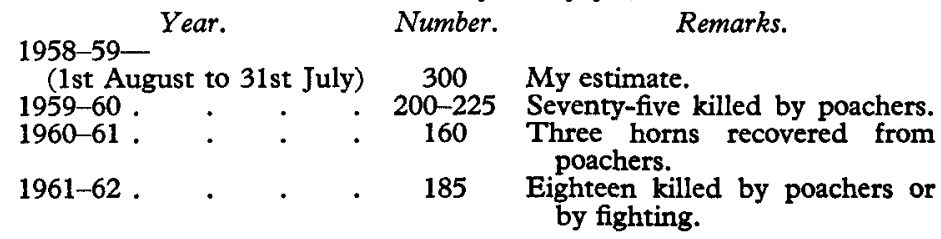

It will be observed that during the two years following my visit in 1959, when there were disturbances and raids from across the Indian border, no less than 140 rhinos were killed by poachers and others. The rhino of the Reu Valley, which is nearest to the Indian border, suffered most and eighteen of their 1959 total of twenty-four have disappeared.

In 1961 the position improved, and the figure for 1961-62 shows an increase of twenty-five rhino. The Rhino Guards appear to have done some good work, as can be gleaned from the following incidents.

In the summer of 1960 a Guard engaged, single-handed, a gang of poachers from India in the hills of the Someswar Range, south of the Reu Valley. He had only twelve rounds of ammunition, but succeeded in killing two of the poachers and used their ammunition to continue the fight. He was wounded twice in the arm and thigh, and was later given Rs. 500 reward.

The other story relates how in January, 1962, the Wild Life Officer sent two local persons up into the hills west of Pokhara to obtain information. A gang was being organized to poach rhino, and a Rhino Guard was then sent up in disguise to get more information of the place, date, and time of arrival of the poachers. So when the poachers eventually arrived at Bandar Bhojaya tapoo in three boats, all the six boatmen and seven poachers were captured and gaoled. Rs. 1,000 was divided between the 


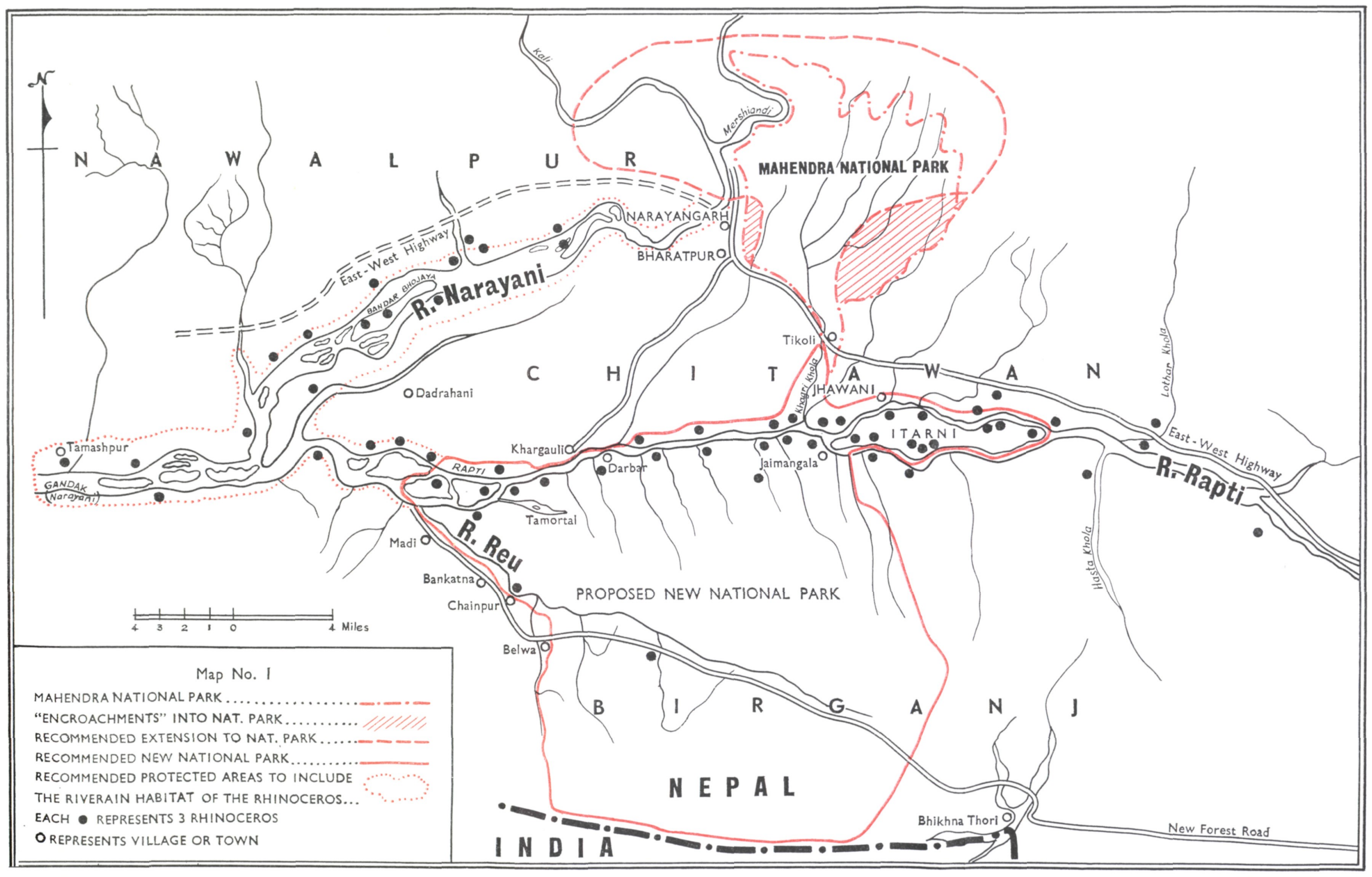




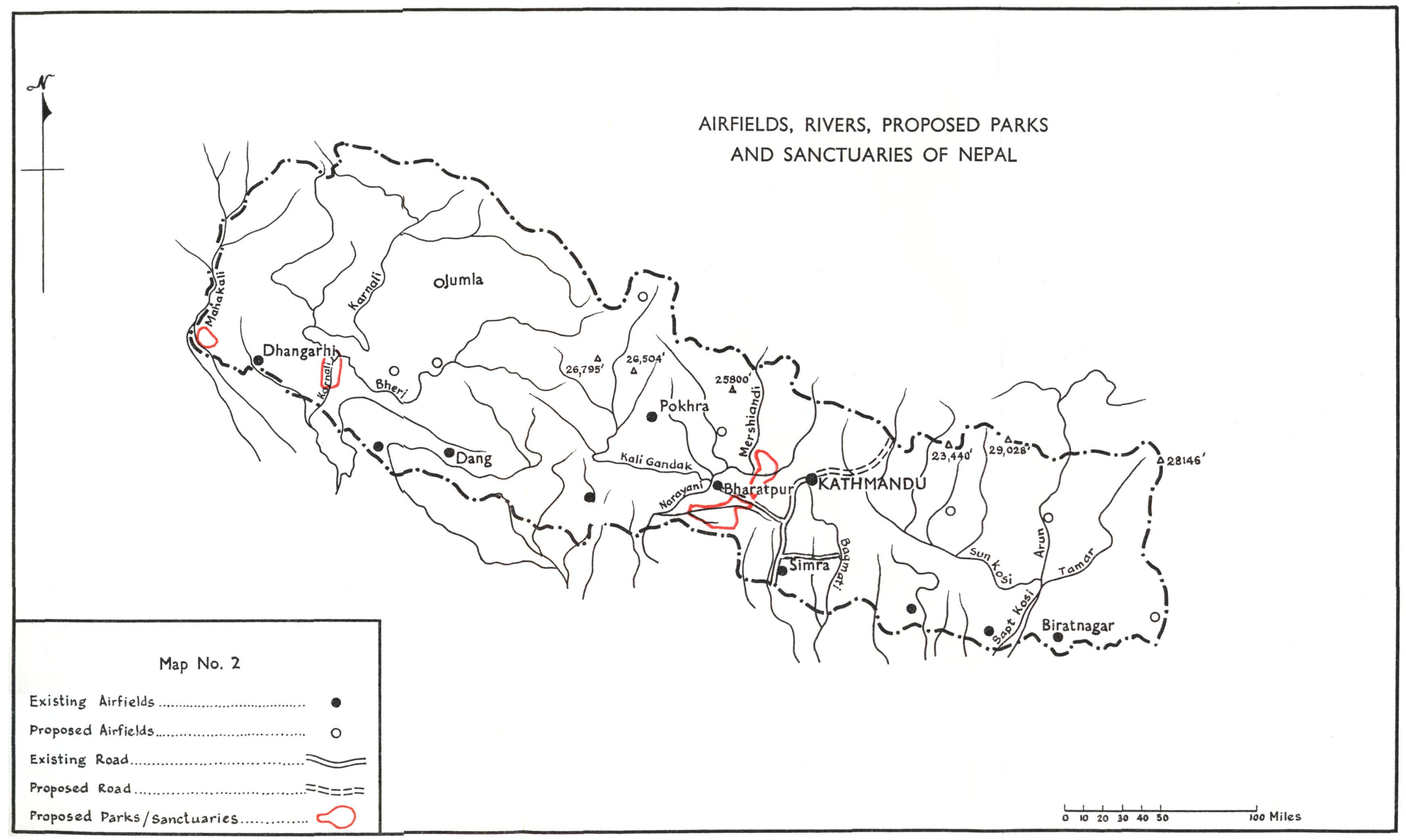

https://doi.org/10.1017/S0030605300002416 Published online by Cambridge University Press 


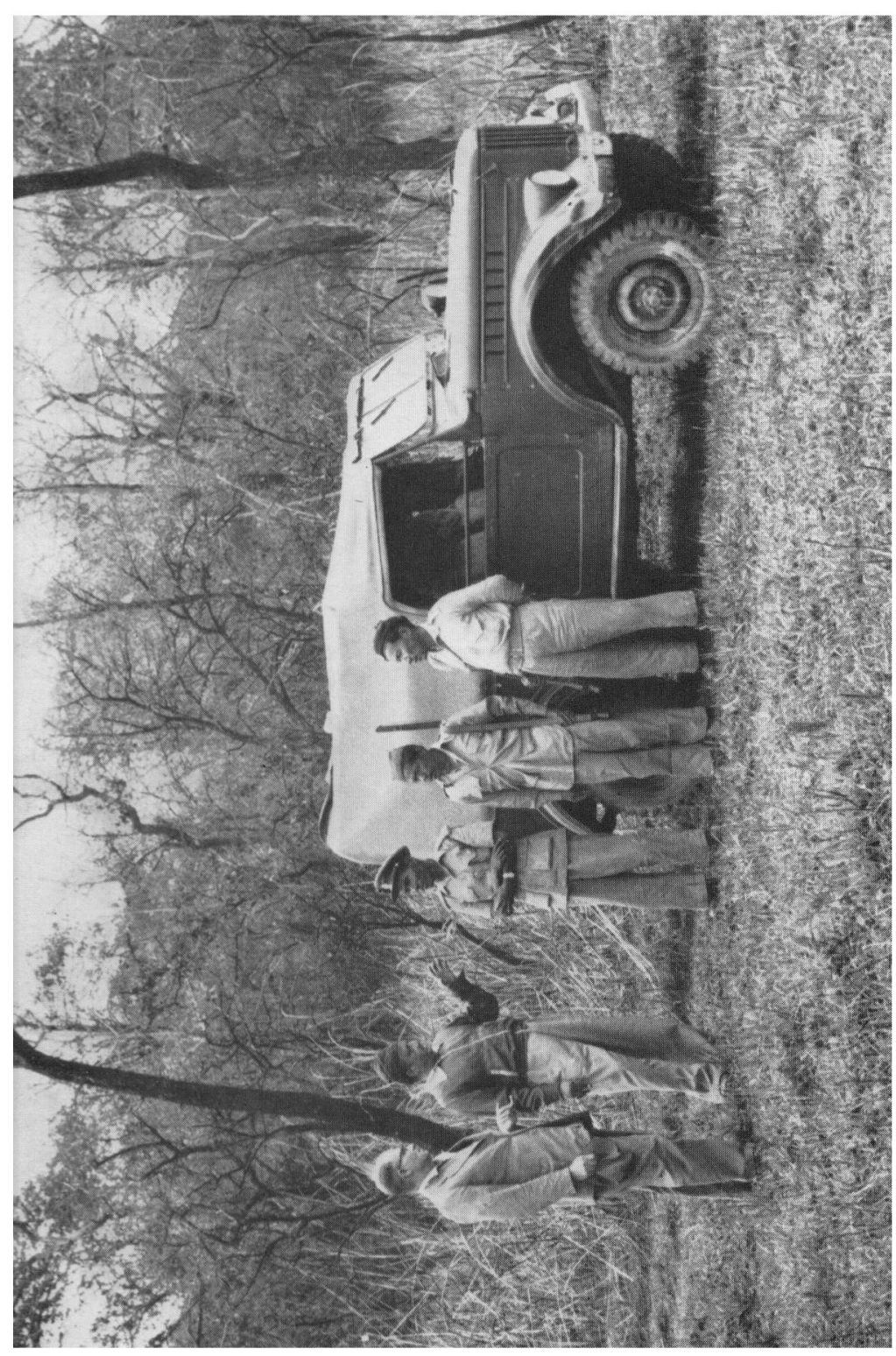

s.

s.

i

$\because 3$

ธิ

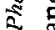

푹

莡

\%

$+$

80

寻

$\Xi$

亗

छ

늠

을

可

.

幽

존

정.

륵

灵

家5

๙

ż

0

s

올

焉

:

ن

0

:

秀

芺

E 


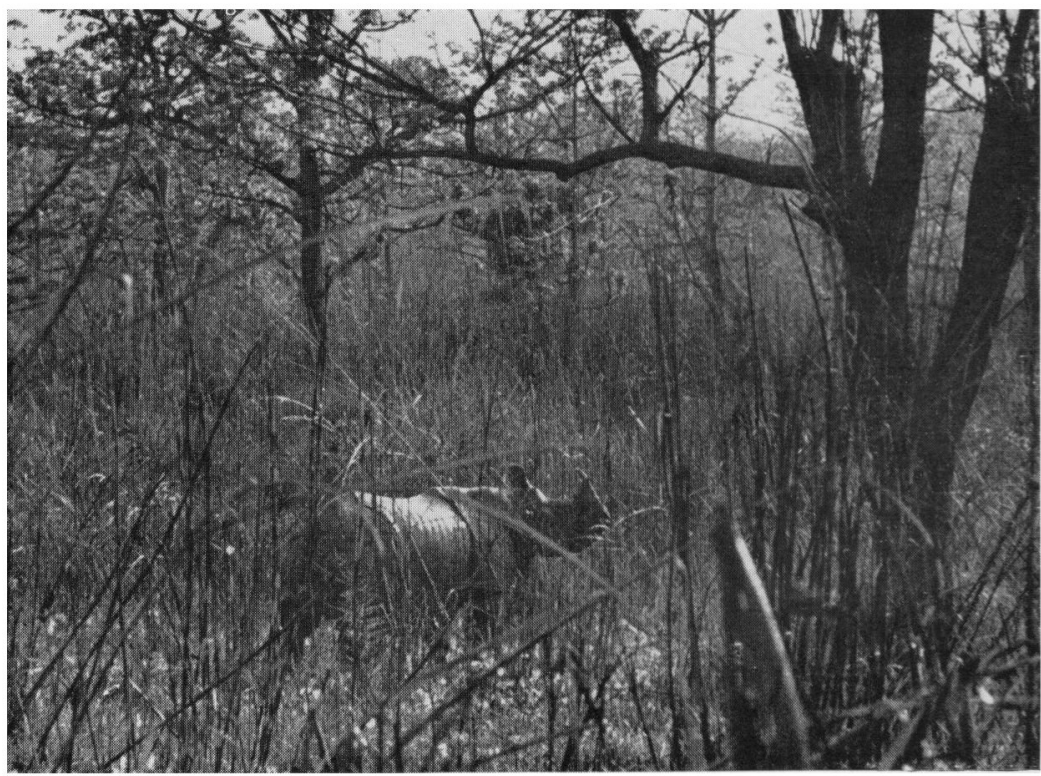

Photo: E. P. Gee.

Rhino in $I$ epal remain hidden in thick cover during daytime, and are usually not found in the open.

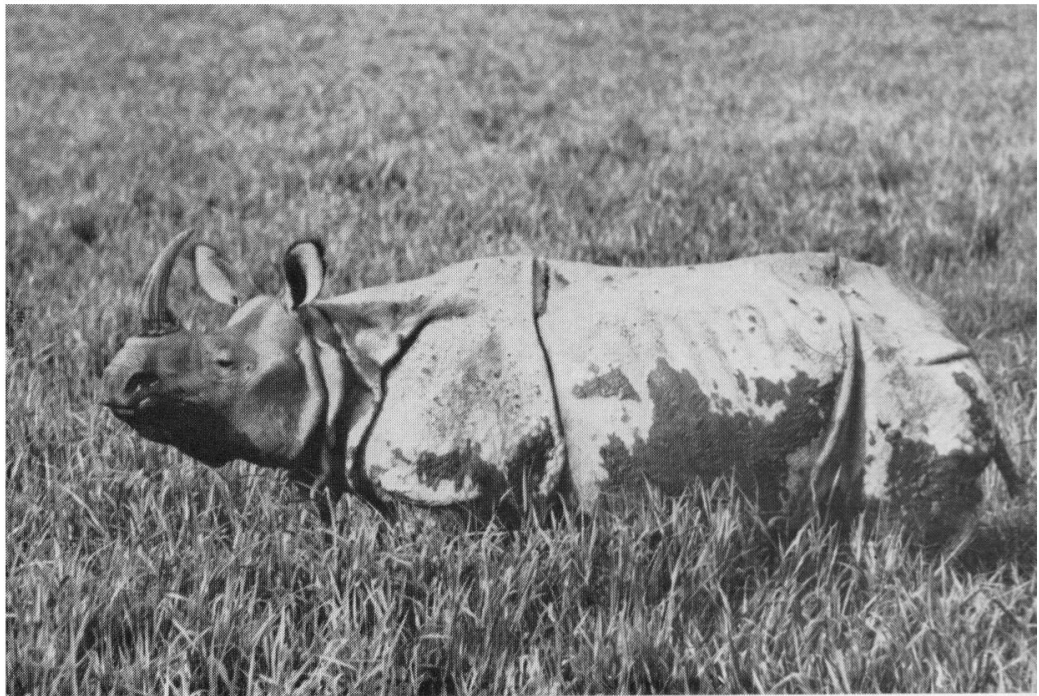

Photo: E. P. Gee.

Rhino in Kaziranga Sanctuary in Assam have become accustomed to human visitors. 
three persons who obtained the valuable information which led to this successful haul of poachers.

Although the price of rhino horn in the India market has fallen from Rs. 2,525 ( $£ 189)$ per lb. to Rs. $2,000(£ 150)$ per lb. during the last two years, the poaching of rhino for its horn still continues whenever opportunity presents itself. Only continued vigilance and severe penalties for poaching in the rhino areas of India and Nepal can save this animal from extermination.

\section{General ACCOUNT OF THE VISIT}

I arrived in Kathmandu by air from Calcutta and Gauhati (in Assam) on 3rd March, 1963. During the course of that morning I met R. G. M. Willan (Chief Conservator of Forests), M. B. Thapa (Deputy Chief Conservator), R. B. Thapa (Conservator), G. N. Rayamajhi (Conservator), and K. M. Tamang (Forest Inventory Specialist). With the aid of a largescale map of Nepal we had detailed discussions on wild life conservation in various parts of the country. During the afternoon I met B. L. Pradhan, the Minister for Forests, Agriculture, and Food and C. Bahadur, K.C., the Forest Secretary.

During 4th March I continued discussions at various levels, and on 5th March I met D. N. Singh, Member for Forests, Agriculture, and Food of the Planning Council. Later I continued collecting information on different parts of the country and on the wild life resources.

On 6th March I was due to fly to Simra, but bad weather prevanted the flight. In the afternoon I met D. N. Pradhan, Director of Tourism, and discussed the need for national parks and sanctuaries for the development of tourism as well as for the preservation of wild life.

7th March was fine and the plane took me to Simra, from where I went with G. N. Rayamajhi and K. M. Tamang into camp at Simri. This forest to the east of Simra, up to the river Bagmati, is good mixed sal forest in the bhabar tract, and here a few chital, barking deer and gaur were seen. The three rhino living in that locality (a cow with calf and a bull) could not be found but their fresh tracks were seen.

On 8th March we jeeped eastwards to the Bagmati river at the point where it leaves the Siwalik Hills. I learnt that this fine though small river is netted almost throughout its length by professional fishermen-who pay nothing whatever for exploiting this valuable natural resource. Under such conditions in India, certain stretches of water are auctioned annually and leased to professional fisherman who pay considerable sums for the monopoly of netting the lower reaches of rivers. Upper reaches of such rivers within Reserved Forests are strictly protected, and permits are issued on payment to sportsmen with rod and line only, thus ensuring a measure of protection and a sustained yield of fish. It is evident that some such system is needed in Nepal, and the Bagmati river is an instance where both professional netting and rod-and-line fishing needs to be instituted in such a way as to bring in much needed revenue to the country and at the same time conserving valuable fish resources.

On 9th March I made the thost important journey of my visit-to the Reu Valley, along a newly-constructed forest road. After discussions in 
Kathmandu it was agreed that I should omit the Rapti Valley during this present visit, since I had covered that area thoroughly in 1959 and since I could obtain all the information about that area from the Forest Officers concerned. I considered it most important that I should visit the Reu Valley, only the fringe of which I was able to see in 1959.

The upper reaches of the Reu Valley, which is south of and roughly parallel to the Rapti, are most unspoilt, ungrazed, and unsettled, and much of the place is ideal rhino habitat with water and the usual species of reeds and grasses. With regular and intensive burning of these climax reeds and grasses, the suitable sub-climactic vegetation would result, and the place would become ideal for rhino and other herbivorous animals.

We halted at various points, and discussed the effects of early and late burning, intensive and widespread burning as opposed to localized and patchy burning, and so on. I learnt from the Rhino Guards that the twenty-four rhino estimated there in 1959 had become reduced by poachers to six. With more settled conditions now prevailing, this valley together with the southern bank of the Rapti, could well be constituted as a new national park and permanent home of the valuable rhino and other wild life.

On 10th March we returned to Kathmandu, and on the 11th March I had more discussions with Forest Officers in Singha Darbar. In the afternoon I was privileged to meet B. B. Thapa, Minister for Home, Law, and Panchayat, and later I met also D. N. Singh, Member of the Planning Council for Forests, Agriculture, and Food, and P. Bahadur, Member of the Planning Council for Statistics, Survey, etc. In the evening I met General Kiran, who was so helpful to me during my 1959 visit.

On 11th March I again met B. L. Pradhan, Forest Minister and was able to give him my impression of the Reu Valley and some details of a proposal to create a national park in that area. Then I flew to Lucknow in company with R. G. M. Willan, L. B. Rana, Conservator of Forests of Kanchanpur, and K. M. Tamang. From Lucknow we caught a train on 13th March to western Nepal, and arrived at Dhangharhi on 14th March.

15th March saw us in camp at Chisapani at the foot of the gorge of the mighty Karnali river, and on 16th March we went up the gorge for several miles. This river is teeming with mahseer (Barbus tor) and other valuable fish. Some local fishermen were fishing with very crude home-made bamboo rods, bazaar lines, and without any reels. One of them alone caught four fish averaging about 30-40 lb. each in the space of 2 hours, on "live bait".

As in the case of the smaller Bagmati there is no organization for the management and wise use of this food supply. There is an opportunity for creating a sanctuary or national park of at least a portion of the hilly area of this river together with a portion of the lower reaches of the river and adjacent forests. Shortly afterwards R. G. M. Willan camped on the Karnali (here called the Girwa) some miles south of the gorge, and has reported favourably on its suitability as a sanctuary for wild life, and of course there is the added attraction of first-class fishing.

On 17th March we jeeped across country, for roads are practically nonexistent in this and most other parts of Nepal, to Singpur-a tiny village 
near a proposed sanctuary at a locality known as Sukla in the extreme south-western corner of the country. During 18th March we saw a large number of swamp deer, with a few chital, blackbuck, and hog deer, and on 19th March we jeeped to the barrage across the Mahakali river, and thence northwards to the Siwaliks.

The area round Sukla is mostly flat grassland, but it also contains some forest, some small swamps and streams, and a small lake. I would not advise the very costly catching and transporting of rhino from the Rapti into this part of Nepal, because these animals are great wanderers and might stray across the border into India. Also the local villagers, being unused to rhino which are incurable crop-raiders, would not be well disposed towards such a venture. But the existence of considerable numbers of wild life makes the creation of a wild life sanctuary at Sukla a top priority.

In the evening of 19 th March I returned to India.

\section{Status, Distribution, and Future of the Rhinoceros AND OTHER Important Fauna IN Nepal}

Rhinoceros.-As shown earlier, the 300 rhino estimated by me in 1959 had dwindled to about 160 by 1961, due to increased poaching during an unsettled political period. With more stable conditions the number was estimated to have increased to 185 by 1962 , and I was informed that at the time of my visit in March, 1963, poaching was definitely on the decrease.

The outlook for the preservation of rhino in Nepal, therefore, is brighter now than before, provided that the Government continue to bear in mind that such wild animals are of greater economic value to a country if they are kept alive than if they are killed and become just so much weight of dead meat. In other words, their potential attraction for tourists from abroad is a full justification for their preservation.

The three rhino which have strayed eastwards to the forests near Simri may be left there, and those forest blocks should be so controlled that only animals open for shooting can be shot by sportsmen after obtaining permits, and no protected animals can be shot.

As stated earlier, I am personally not in favour of the costly trapping and transporting of rhino to other parts of Nepal. If some of the rhino from the more densely settled and cultivated portions of the Rapti Valley can be driven by government elephants into the Reu Valley it would be a very wise and commendable step. There I estimate the holding capacity to be about forty to fifty rhino provided that burning of dense reeds and grass is effectively done.

In Map No. 1 each black dot represents three rhino as estimated during my visit, after close consultation with the Conservator concerned, G. N. Rayamajhi. A total of sixty dots are shown on the map, totalling 180 rhino in this area ; and with the three rhino in the Simra/Simri forest the total comes to 183 rhino-which is nearly the same as the 185 given as the present number of rhino existing in Nepal. The break-down of the figure of 180 works out as follows : Nawalpur eleven dots or thirty-three rhino, Bandar Bhojaya tapoo two dots or six rhino, north of Rapti river seventeen dots or fifty-one rhino, Rapti islands twelve dots or thirty-six rhino, south 
of Narayani and Rapti rivers sixteen dots or forty-eight rhino, Reu Valley two dots or six rhino.

Deer.-In the Sukla area of Kanchanpur in south-west Nepal, there is a good opportunity of protecting the rare blackbuck and the swamp deer, as well as other species of deer, by the creation of a wild life sanctuary. Bengal florican also exist there, and need strict protection.

The Bardia Forest is said to contain all the species of deer in Nepal, and this might be worth considering as a sanctuary. The reaches of the Karnali (Girwa) river south of the gorge would be even more worthwhile as a sanctuary or natural park, because of the added attraction of mahseer fishing and beautiful river scenery. Parts of the upper reaches in the Siwaliks and in the Mahabharat Range could also be included.

Wild Buffalo (Bubalus bubalis). - I found it difficult to obtain accurate information about the numbers and status of wild buffalo said to exist near Lahi on the Sapt Kosi, just north of the Indian border. It is desirable that a study be made of these few remaining animals and steps devised to preserve them, especially as this species has become extinct in the nearby Bihar and West Bengal States of India.

Rivers and Fish.-In the planning of hydro-electric and irrigation projects, it is obvious that the protection of the catchment areas and of the surroundings of the impounded water is highly desirable in order to prevent soil erosion, silting up of the reservoirs, contamination of the water, and so on. It follows, therefore, that in such areas careful planning should include provision for general nature conservation, including the creation of national parks and sanctuaries.

As such areas require forest cover, either in the form of protecting the existing vegetation or of afforestation, the Forest Department needs to be closely associated with their planning. And as such areas are often of outstanding scenic beauty, they certainly deserve careful consideration as possible national parks or wild life sanctuaries.

The fish resources of Nepal appear to be as enormous as they are at present totally uncontrolled and unexploited. The netting of fish by professional fishermen in the lower reaches of rivers needs to be regulated and allowed only on a lease system on payment of reasonable fees. Fishing by sportsmen with rod and line only, on a permit system, in the upper reaches of rivers will ensure the necessary protection for fish in the spawning season, thus ensuring an ample sustained yield of fish.

Certain rivers at higher elevations could well be stocked with brown trout from Kashmir, as has been done in the Kulu Valley and Bhutan. This would provide a wonderful opportunity for attracting touristsespecially if such rivers could be included in scenic national parks or sanctuaries.

High Elevation Fauna.-It is urgently necessary that at least some places in the Himalayas be set aside for the preservation of the unique high elevation fauna such as the various species of mountain sheep and mountain goats, snow leopard, brown bear, musk deer, and others. Such places are certain to possess great scenic beauty. It only remains to make them accessible to visitors to produce national parks of the grandeur of those famous places in the Rocky Mountains of the United States and Canada. 


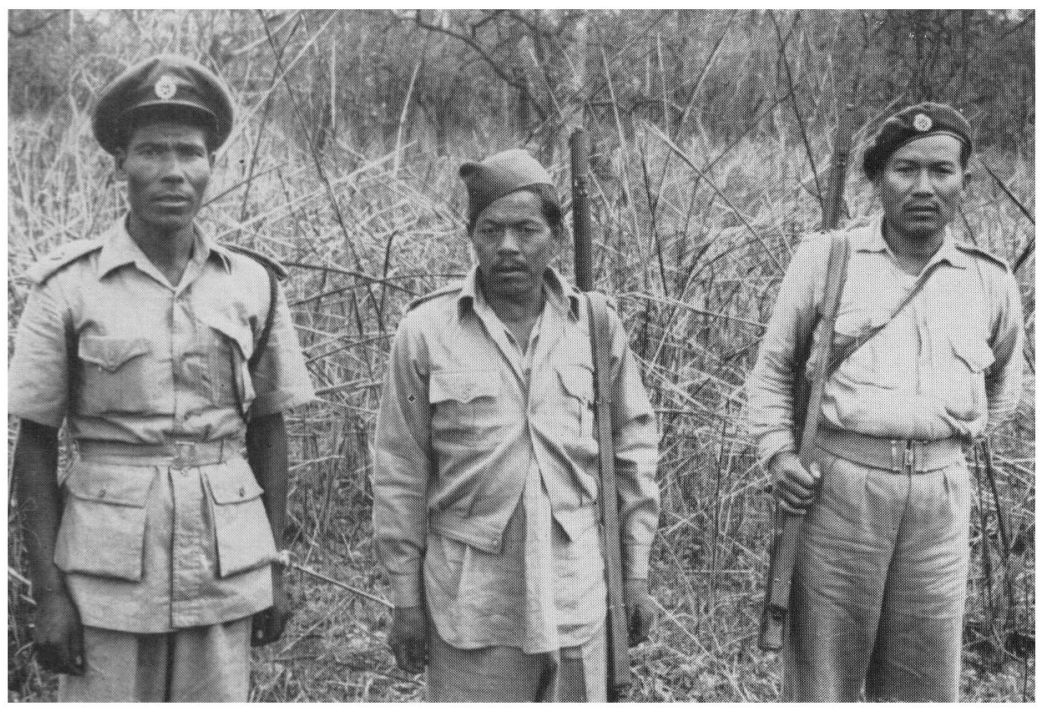

Photo: E. P. Gee.

A Subedar and two of the Rhino Guards.

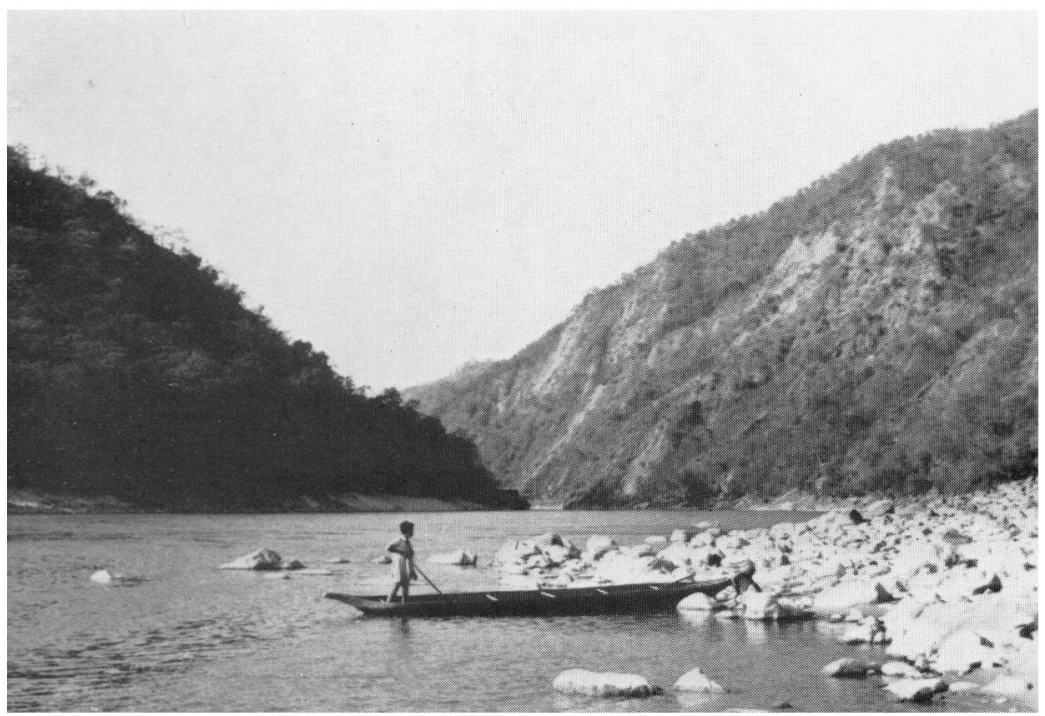

Photo: E. P. Gee.

The gorge of the Karnali river. 


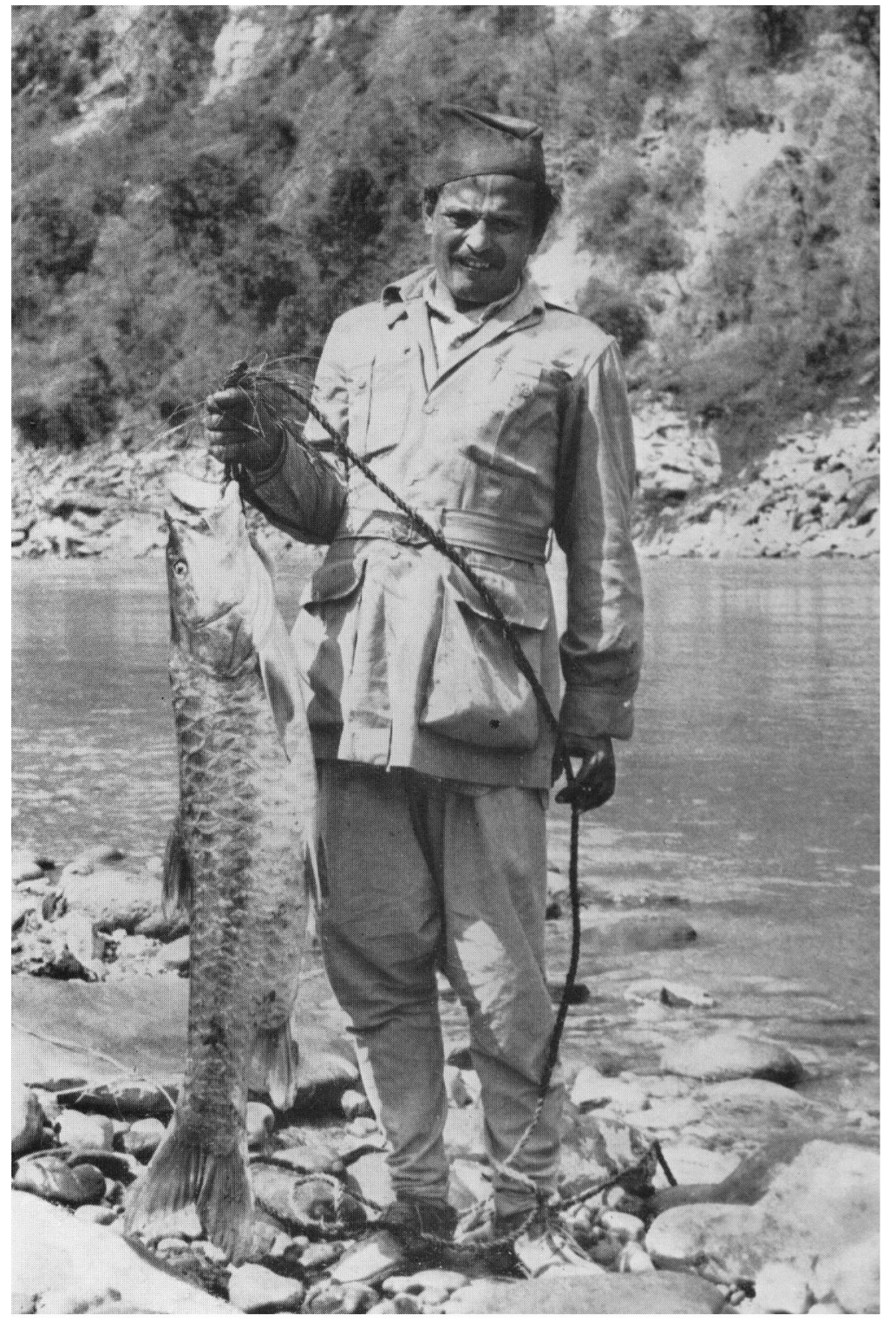

Photo : E. P. Gee.

A Mahseer of about 30-40 lb. caught on home-made tackle in the Karnali river. 
Several airfields are proposed in some of the more inaccessible parts of central and northern Nepal, and possibly some of these might provide access to high elevation national parks. The proposed road from Kathmandu northeastwards into Tibet might also run near them.

There is no doubt that tourism could eventually prove to be one of Nepal's major industries, and that another Switzerland or Kashmir lies shrouded and unrevealed to the world due only to inaccessibility.

\section{ReCommendations (see Maps 1 and 2)}

The following recommendations are made :-

(1) That the Government of Nepal officially recognize (a) the importance of the country's wild life as a valuable natural resource, and $(b)$ the necessity of adequately protecting and utilizing this resource for the benefit of the people.

(2) That a Wild Life Division or Branch of the Forest Department be established to take charge of parks and sanctuaries and enforcement of all wild life legislation.

(3) That a survey of the country's fauna be carried out, preferably by an experienced biologist who might be obtained from abroad under a grant or fellowship.

(4) That the Mahendra National Park be re-constituted by an act of the Legislature, with the settled portions excluded, and with a new portion to the north included.

(5) That the area south of the Rapti but including as much of the riverain tract as possible (especially the island of Itarni) and including the upper reaches of the Reu Valley, be constituted by a separate act of the Legislature as a national park. Roads southwards from Kargauli or Tikoli across the Rapti, and across the Churia Range to the Reu Valley, possibly via Durbar and Tamar Tal, are required to provide access to the park. This would be the main stronghold of the rhino and other fauna of Nepal.

(6) That the area round Sukla in south-west Nepal, and the area north and south of the gorge of the Karnali river, and any other such area found suitable for the purpose, be constituted as national parks or wild life sanctuaries for the preservation of the country's low elevation fauna. The few remaining wild buffalo on the Sapt Kosi should not be overlooked when these measures are being contemplated.

(7) That a search be made for suitable areas in the Himalayas for the creation of scenic national parks and for the preservation of the country's high elevation fauna, preferably areas which would become accessible when new airfields and new roads are constructed.

(8) That the country's existing river fish resources be managed in such a way as to ensure a sustained yield of valuable protein food and muchneeded revenue, and that trout be introduced into some of the high elevation rivers. Both these steps could well be taken in conjunction with the constitution of national parks and sanctuaries for the preservation of the country's wild life and scenic beauty.

(9) That the Wild Life Advisory Board be re-constituted and that an official wild life policy be formulated and recommended to Government, 
and that wild life preservation and bona fide sport be organized on a sound basis with protected species and closed seasons. This Board could also undertake publicity in order to develop a consciousness among the people of the cultural and economic value of wild life and nature conservation, and could encourage tourism as an important economic factor in support of wild life preservation.

(10) That selected Officers of the Forest Department be deputed to visit and study some of the adjacent parks and sanctuaries of India, especially Kaziranga and Manas in Assam, Jaldapara in West Bengal and Corbett National Park in Uttar Pradesh.

\section{ACKNOWLEDGMENTS}

My visit was made possible by a grant from the Fauna Preservation Society of London, towards my travelling and incidental expenses, and by the courteous invitation of the Forest Department of Nepal.

I am particularly indebted to R. G. M. Willan and Mrs. Willan, who extended to me such warm hospitality during my stay in Kathmandu. I am also most grateful to those Officers of the Forest Department with whom I came into contact, especially those who accompanied me on my tours to south and southwestern Nepal.

\section{Literature Consulted}

GEE, E. P. (1959), "Report on a Survey of the Rhinoceros Area of Nepal, March and April, 1959," Oryx, Vol. V, No. 2 (August, 1959).

\section{Glossary of Local Terms}

bhabar dry country, with a subsoil of boulders, at the foot of the Himalayas

dun a plateau in a valley or a flat valley in the foothills of the Himalayas

khola a stream

panchayat a committee or council, literally of five members, at any level sal

tal a hardwood species of tree of great commercial value

tapoo

terai a small lake an island in a river moist country a few miles from the base of the Himalayas, at the edge of the bhabar. 